\title{
ANALISIS PENGEMBANGAN VARIASI MENGAJAR GURU SEKOLAH MINGGU
}

\author{
Hisardo Sitorus \\ Institut Agama Kristen Negeri Tarutung \\ Email: hisardositorus@yahoo.com
}

\begin{abstract}
Abstrak: Tujuan penelitian ini adalah untuk menganalisis pengembangan variasi mengajar guru sekolah minggu. Penelitian ini dilakukan di GKPI Lumban Inaina Resort Siborongborong Wilayah Humbang Tahun 2017. Metode penelitian ini adalah metode kuantitatif deskriptif. Responden penelitian ini adalah guru sekolah minggu berjumlah 40 Orang. Melalui hasil perhitungan akumulasi setiap Indikator yang telah diperoleh dari lapangan: 1. Variasi suara dan sikap guru sejumlah 42,97222 masuk dalam kategori cukup. 2. Variasi media dan bahan sejumlah 49,65789 dalam kategori cukup. 3 Variasi interaksi sejumlah 52,46154 dalam kategori cukup. Berdasarkan pembahasan hasil maka hipotesa dirumuskan melalui penelitian bahwa terdapat variasi mengajar guru sekolah minggu masih dalam kategori cukup. Artinya dalam menjalankan tugas dan tanggung jawabnya guru sekolah minggu masih memprihatinkan untuk itu perlu diberikan pengetahuan tentang penguasaan variasi mengajar yang mencakup: bagaimana seharusnya variasi suara dan sikap guru mengajar yang lebih baik? apa media dan bahan yang harus diperlukan? dan bagaimana menerapkan variasi interaksi sehingga masuk dalam kategori kuat atau sangat kuat?
\end{abstract}

Kata-kata kunci: Mengajar Guru, Sekolah Minggu

\section{PENDAHULUAN}

Sekolah minggu merupakan kegiatan gereja yang harus dapat diakses oleh semua anak-anak kristen. Untuk menjangkau dan membawa setiap orang kepada Tuhan Yesus serta mengajarkan Firman Tuhan untuk mengubah kehidupan mereka menjadi pengikut Yesus yang bertumbuh dalam kerohanian yang penuh dengan pengharapan akan janji keselamatan. Oleh karena hal tersebutlah sekolah minggu merupakan bagian yang sangat penting dalam kehidupan gereja yang dikhususkan kepada anak-anak. Anak sekolah minggu merupakan generasi jemaat kristen masa depan yang harus diberikan pengajaran Firman Tuhan. Pihak yang terlibat dalam mengajarkan Firman Tuhan bagi anak sekolah minggu adalah majelis gereja dan khususnya guru sekolah minggu.

Guru sekolah minggu merupakan orang yang sesungguhnya bertanggung jawab atas pelayanan kepada anak sekolah minggu dan sekaligus menjadi rekan kerja orangtua dalam membina, mendidik anak sekolah minggu sesuai ajaran Tuhan. Guru sekolah minggu terjun dalam pelayanan gerejawi merupakan suatu jabatan rohani yang kudus karena merupakan panggilan oleh Allah. Guru sekolah minggu setidaknya harus memiliki ilmu paedagog, ilmu psikoligi dan ilmu teologi. Pengembangan Pengetahuan guru sekolah minggu dapat melalui belajar mandiri, mengikuti seminar dan lokakarya dan pelatihan maupun perkuliahan. Oleh karena itu guru sekolah minggu harus senantiasa mengembangkan dan melengkapi diri demi pengajaran yang bervariasi, bekualitas, inovatif. Mengetahui berbagai strategi, model serta metode pengajaran yang sesuai dengan kemampuan perkembagan anak dan sesuai dengan materi pengajaran. Pengajaran dengan berbagai variasi media atau alat pengajaran, variasi suara dan variasi sikap guru maupun variasi interaksi merupakan hal yang sangat mempengaruhi keberhasilan pengajaran. Dengan melalukan pengajaran bervariasi akan dapat menimbulkan semangat, keinginan serta meningkatkan kemudahan 
mengetahui Firman Tuhan. Karena tugas guru bukan hanya memberikan pengetahuan semata, melainkan melakukan usaha-usaha

agardapat menumbuhkan semangat dan kemudahan belajar.

Sementara hasil pengamatan di sebahagian gereja bahwa guru sekolah minggu melakukan pengajaran belum mengacu pada potensi guru yang diharapkan. Hal tersebut dapat terlihat dari kondisianak, misalnya pada saat guru mengajar masih banyak anak-anak yang suka menghayal, mengganggu teman, berkelahi dengan teman, ribut, dan keluar masuk gereja, sering berbicara tidak santun, Oleh karena itu Firman Tuhan yang disampaikan oleh guru sekolah minggu tidak lagi didengar dan bahkan hanya dianggap sebagai angin lalu yang sebagian bertahan hanya sebentar saja. Tidak dapat disangkal bahwa hal itu terjadi adalah karena begitu sulitnya mendidik anak sekolah minggu apabila tidak dibarengi dengan kemampuankhusus dalam mengajar anak. Sementara banyak guru sekolah minggu yang melakukan tugasnya hanya dibekali pendidikan Sekolah menengah Pertama (SMP), Sekolah Menengah Atas (SMA) dan yang masih SMA. Yang menjadi pertanyaan adalah: Apakah gereja beranggapan bahwa pelayanan guru sekolah minggu sebatas pelayanan sampingan atau sebatas pengisi kekosongan pelayan yang tidak pernah menjadi bagian pelayanan utama gereja sehingga kurang memperhatikan sumber daya guru sekolah minggu? Sekolah minggu lahir abad ke-18 dan usia sekolah minggu saat ini sudah sangat tua, namun mengapa majelis gereja hingga saat ini belum meningkatkan potensi guru sekolah minggu? Apakah karena anak sekolah minggu tidak mampu memberi persembahan yang lebih layak ke gereja sehingga gereja tidak mampu meningkatkan fasilitas pembelajaran sekolah minggu? Apabila ditinjau dari sisi ekonomisnya kegiatan sekolah minggu boleh saja mendevisitkan anggaran gereja, namun demikian anak sekolah minggu merupakan generasi masa depan gereja yang harus ditumbuh kembangkan melaui ajaran Tuhan.

Guru sekolah minggu masih jarang dan bahkan ada yang belum pernah mengikuti seminar, lokakarya, pelatihan atau pendidikan tentang mengajar anak sekolah minggu. Mereka melakukan tugas tersebut hanya didasari kemauan, ketulusan mengajar dan sekali-kali mereka belajar mandiri dari buku pedoman mengajar sekolah minggu. Hal ini tentu sangat memprihatinkan sebab bagaimana mungkin anak- anak menerima Firman Tuhan dengan lebih baik sementara guru sekolah minggu sendiri tidak pernah mendapatkan pengajaran dan belajar Firman Tuhan dengan lebih baik dan apabila guru yang mengajar hanya mencoba-coba mengajar.Kemampuan guru sekolah minggu merupakan kemampuan yang ditetapkan dan diberikan oleh Allah melalui proses belajar guru tersebut, sama seperti seorang ahli bangunan yang meletakkan dasar yang kokoh tentang Yesus Kristus kepada anak-anak sebagai bekal masa depan yang gemilang (Siswanto 2008:18).

Melalui pengamatan masih di temukan berbagai kekurangan dalam pelayanan sekolah minggu:

1. Pengajaran sekolah minggu yang kurang berkualitas.

2. Keterbatasan fasilitas pembelajaran.

3. Kurangnya kepedulian majelis gereja terhadap peningkatan sumber daya guru sekolah minggu.

4. Majelis gereja belum menetapkan anggaran dana rutin termasuk honor atau dana transport guru sekolah minggu.

Dari berbagai masalah di atas dapat dipahami bahwa masalah dalam pelayanan sekolah minggu sebahagian besar justru timbul dari dalam gereja itu sendiri. Hal inilah yang memotivasi penulis ingin melakukan penelitian di gereja melalui penelitian terhadap guru-guru sekolah 
minggu untuk menganalisis variasi mengajar guru sekolah minggu melalui penelitian ini.

\section{Batasan Masalah}

Analisis pengembangan dan variasi mengajar guru sekolah minggu di GKPI Lumban Inaina Resort Siborongborong Wilayah Humbang Tahun 2017?

3. Rumusan Masalah

Bagaimana pengembangan dan variasi mengajar guru sekolah minggu di GKPI Lumban Inaina Resort Siborongborong Wilayah Humbang Tahun 2017?

4. Tujuan Penelitian

Untuk mengetahui bagaimana pengembangan dan variasi mengajar guru sekolah minggu di GKPI Lumban Inaina Resort Siborongborong Wilayah Humbang Tahun 2017?

\section{PEMBAHASAN}

1. Variasi Mengajar Guru Sekolah Minggu

\subsection{Variasi}

Pengertian variasi menurut kamus ilmiah popular adalah selingan, selang-seling, atau pergantian. Variasi mengajar merupakan keanekaragaman dalam penyajian kegiatan mengajar agar anak lebih berkonsentrasi (Peterson 1995:116). Variasi adalah keanekaan yang membuat sesuatu agar tidak monoton. Variasi dalam kegiatan pembelajaran dapat menghilangkan kebosanan, meningkatkan perasaan senang dan meningkatkan keingintahuan anak, serta meningkatkan kadar keaktifan anak (Chalke 2009:105). Variasi mengajar merupakan pengubahan tingkah laku, sikap dan perbuatan guru dalam konteks belajar mengajar yang bertujuan untuk mengatasi kebosanan anak sehingga anak memiliki semangat belajar yang tinggi terhadap pelajarannya. Dan ini bisa dibuktikan melalui ketekunan, antusiasme, keaktifan mereka dalam belajar dan mengikuti pelajarannya (Tim Pustaka Familia 2006:40).

\subsection{Guru Sekolah Minggu}

Guru sekolah minggu merupakan oknum yang bertugas melaksanakan pengajaran Firman Tuhan bagi anak di gereja setiap hari minggu dan hari besar umat kristiani. Laheba (2007:16) dalam bukunya mengatakan bahwa "Guru sekolah minggu sebagai mitra Allah dalam mendidik anak dalam Pendidikan Agama Kristen demi pelaksanaan dan penggenapan kerajaan Allah. Selanjutnya Leo (2008:3) berpendapat bahwa "Guru Sekolah Minggu adalah mantan murid sekolah minggu atau jemaat yang terpanggil melayani atau pelayan- pelayan sejati yang berkomitmen". Lebih lanjut Tong (1993:7) berpendapat bahwa "guru sekolah minggu adalah orang yang berusaha untuk memikul dan menelan segala kepahitan sendiri dan berusaha untuk selalu siap sedia menolong murid-murid yang memerlukannya tanpa merasa diri sendiri diganggu.

\subsection{Anak Sekolah Minggu}

Anak sekolah minggu merupakan individu yang belum mempunyai kemandirian dalam berbagai aktifitasnya sehingga perlu diberikan pengajaran Firman Tuhan sebagai fundasi hidup beriman. Menurut Dodson (1996:327) bahwa "Anak dalam usia dan kempuanya dapat dibagi atas tiga kelompok yaitu 1. Usia Pra-sekolah (3- 5 Tahun), 2. Usia pertengahan masa anak-anak (6-9 Tahun), 3. Masa Pra-remaja (10-12 Tahun)". Anak sekolah minggu uumnya digolongkan kedalam tiga tahapan kemampuan berdasarkan usianya.

Dari pendapat ahli tersebut bahwa variasi mengajar guru sekolah minggu merupakan kemampuan dasar yang harus dimiliki guru supaya anak tidak bosan dalam menerima pengajaran dan lebih mudah mengerti pengajaran sehingga anak dapat percaya kepada Yesus. Variasi mengajar dapat dipahami dan diaplikasikan guru dengan cara pengembangan potensi diri melalui latihan dan pendidikan guru. Pengajar yang terpanggil melayani dan sekaligus menjadi mitra Allah, berusaha untuk selalu siap sedia menolong murid-murid yang memerlukannya tanpa merasa diri sendiri 
diganggu,tanpa merasa pribadinya terganggu dalam meletakkan dasar yang kokoh tentang Firman Tuhan kepada anak-anak sebagi bekal mereka untuk masa depan.

2. Dimensi-dimensi Variasi Mengajar Guru Sekolah Minggu

Beberapa dimensi yang harus diperhatikan juga dalam variasi mengajar adalah sebagai berikut dikemukakan oleh Fathurrohman (2009:95-96) :

1. Variasi suara dan sikap guru

Suara guru memiliki peranan penting dalam melahirkan kualitas variasi mengajar. Karena itu, intonasi, nada, volume dan kecepatan suara guru perlu diatur dengan baik. Dalam konteks di atas, beberapa hal perlu diperhatikan guru, sebagai berikut:

a. Penekanan: penekanan inti pelajaran/kata kunci pelajaran

b. Pemberian waktu: kesempatan kepada siswa untuk bertanya

c. Kontak pandang: membagi perhatian kepada siswa

d. Gerakan anggota badan: memberikan tepukan tangan, jempol

e. Pindah posisi: tidak hanya fokus pada satu tempat saja

2. Variasi media dan alat pengajaran Penggunaan alat yang multi media dan relevan dengan tujuan pengajaran dapat meningkatkan hasil belajar sehingga lebih bermakna dan tahan lama. Adapun variasi penggunaan alat antara lain:

a. Variasi alat atau bahan yang dapat dilihat: alat atau media yang termasuk kedalam jenis ini ialah yang dapat dilihat, antara lain grafik, bagan, poster,gambar, filim dan slide.

b. Variasi atau bahan yang dapat didengar: suara guru termasuk kedalam media komunikasi yang utama dikelas. Rekaman suara, suara radio, musik, telepon dapat dipakai sebagai pengguna indera dengar yang divariasikan dengan indera lainnya. c. Variasi alat atau bahan yang dapat diraba, digerakkan misalnya: peragaan yang dilakukan oleh guru atau siswa,model, topeng dan boneka, dapat digunakan oleh anak didik dan dapat diraba.

d. Variasi alat atau bahan yang dapat didengar, dilihat dan diraba, media yang dapat digunakan misalnya: filim,televisi, radio, slide projector yang diiringi penjelasan guru, tentu saja penggunaanya disesuaikan dengan tujuan pengajaran yang hendak dicapai.

3. Variasi interaksi

Variasi dalam pola interaksi antar guru dengan anak didiknya memiliki rintangan yang bergerak dari dua kutub, yaitu:

a. Anak didik bekerja atau belajar secara bebas tanpa campur tangan dari guru

b. Anak didik mendengarkan dengan pasif, situasi didominan oleh guru dimana guru berbicara dengan anak didiknya

Dari pendapat tersebut diuraikan kembali bahwa variasi mengajar sangat diperlukan dalam proses belajar mengajar anak sekolah minggu. Apabila ketiga komponen tersebut dikombinasikan dalam penggunaanya atau secara integritas maka akan mengikatkan perhatian anak sekolah minggu, membangkitkan keinginan dan kemampuan. Dalam proses belajar mengajar ada variasi bila guru sekolah minggu dapat menunjukkan adanya perubahan dalam gaya mengajar, media yang digunakan berganti-ganti dan ada perubahan dalam pola interaksi anatar guru dengan anak, anak dengan guru, anak dengan anak. Variasi lebih bersifat proses maupaun produk.

3. Syarat dan Tugas Guru Sekolah Minggu Menurut Setiawani (2005:7-9) seorang guru

sekolah minggu haruslah memenuhi delapan syarat yakni :

1. Seorang yang telah lahir baru/ diselamatkan

2. Seorang kristen yang bertumbuh 
3. Seorang kristen yang setia terhadap gereja

4. Seorang yang memahami bahwa pelayanan pendidikan adalah panggilan Allah

5. Seorang yang suka dengan objek yang didiknya

6. Seorang yang baik dalam kesaksian hidupnya

7. Seorang yang telah menerima latihan dasar sebagai guru

8. Seorang yang melayani dengan bersandar pada kuasa Roh Kudus

Selanjutnya yang menjadi tugas seorang guru sekolah minggu menurut Paulus (2003:123-124) adalah:

1. Menyiapkan setiap pertemuan setiap hari minggu dengan berbagai acara/lagu/ cerita/aktivitas yang kreatif, sehingga sekolah minggu tidak menjadi pertemuan yang rutin dan monoton. Sekolah minggu diharapkan penuh variasi yang bukan saja menyenangkan anak, melainkan juga membuat anak semakin mengenal Yesus Kristus dan bertumbuh dalam segala hal seperti yang Yesus inginkan.

2. Mengikuti persiapan mengajar serajin mungkin.

3. Membuat alat peraga sebaik mungkin.

4. Membuat tata ruang kelas variatif agar tidak monoton.

5. Menyiapkan aktivitas anak kreatif yang mengembangkan seluruh potensi anak.

6. Mengembangkan diri sebagi seorang guru harus terus aktif mengembangkan dirinya dengan banyak membaca buku dan menerapkan serta mengembangkan pengetahuan yang diperoleh. Seorang guru juga haris rajin mengikuti seminar, pelatihan mengajar, pembinaan guru, dan sebagainya.

7. Tugas guru lainnya adalah belajar dari anak- anak sekolah minggu (kebutuhan dan " keinginan" mereka). Tujuannya adalah agar guru semakin memahami anak-anaknya, dan kemudian memikirkan arah pembinaan dan model pembinaan yang tepat.
Jadi dapat disimpulkan bahwa yang menjadi syarat-syarat seorang guru sekolah minggu adalah seorang kristen sejati yang telah menerima latihan dan pendidikan dasar sebagai guru, lahir baru, dengan pribadi yang setia, rendah hati, serta memiliki iman percaya yang teguh kepada Allah sebagai orang yang dipilih dan dipercaya untuk melakukan panggilannya sebagai penginjil kepada anak sekolah minggu. Sedangkan yang menjadi tugas guru sekolah minggu adalah membuat persiapan mengajar, alat peraga, mengembangkan potensinya melalui jalur pelatihan atau pendidikan dan belajar dari anak-anak sekolah minggu.

\section{PENUTUP}

Simpulan

Berdasarkan teori dan hasil penelitian dapat disimpulkan bahwa variasi mengajar guru sekolah minggu masih dalam kategori Cukup. Sehingga dalam menjalankan tugas dan tanggung jawabnya guru sekolah minggu masih perlu meningkatkan kemampuannya. Guru sekolah minggu belum mengetahui bagaimana seharusnya variasi mengajar yang lebih baik, Media dan bahan yang harus diperlukan itu apa saja dan bagaimana seharusnya menerapkan variasi mengajar itu sehingga masuk dalam kategori Kuat atau Sangat kuat.

Saran

1. Hendaknya guru sekolah minggu menyadari perlunya memahami anak sekolah minggu dengan baik, karena tidak seorangpun dapat menjadi guru yang sejati atau mulia tanpa mengembangkan kemampuannya. Oleh karena itu guru harus mampu menjadikan dirinya bagian dari anak dan berusaha memahami anak.

2. Guru sekolah minggu supaya mengembangkan variasi mengajarnya supaya anak sekolah minggu mudah mennerima pengajaran dan lebih semangat beribadah.

3. Guru sekolah minggu masih perlu dibekali 
dengan ilmu pendidikan supaya guru mengetahui bagaimana gaya mengajar yang sebenarnya, bahan dan media apa yang tepat diberikan pada anak sekolah minggu dan dalam mengajar variasi apa saja yang harus dilakukan disesuaikan dengan topik sekolah minggu setia pertemuan.

\section{DAFTAR PUSAKA}

[1] Arikunto Suharsimi. 2010. Prosedur Penelitian. Jakarta:PT Rineka Cipta

[2] Aunurrahman.2010. Belajar dan Pembelajaran. Bandung: Alfabeta

[3] Chalke Steve. 2009. Kiat Menjadikan Anak Anda Sukses dan Bahagia, Yogyakarta:

Andi

[4] Fatturohman Pupuh. 2009. Strategi Belajar Mengajar. Bandung : PT Refika Aditama

[5] Iris V. Cully, 2006. Dinamika Pendidikan Kristen, terj. P. Siahaan \& Stephen Suleeman, Jakarta, BPK Gunung Mulia.

[6] Laheba, Novelina.2007. Guruku Sahabatku,

Yogjakarta: Andi

[7] Leo, Susanto. 2008. Kiat Sukses

Mengelola dan Mengajar Sekolah

Minggu, Yogjakarta:

Andi

[8] Lie, Paulus. 2003. Teknik Kreatif dan Terpadu Dalam Mengajar Sekolah Minggu, Yogjakarta: Andi.

[9] Mary Go Setiawani, 2005. Pembaruan Mengajar, Bandung, Yayasan Kalam Hidup
[10] Nicolas P. Woltrerstroff, 2007. Mendidik Untuk Kehidupan: Refleksi Mengenai Pengajaran dan Pembelajaran Kristen, terj. Lana Asali, Surabaya, Momentum.

[11] Peterson Lindi. 2004. Bagaimana Memotivasi Anak Belajar. Jakarta:

Grasindo

[12] Syaiful Bahri Djamarah \& Aswan Zain.(2010). Strategi Belajar Mengajar. Jakarta: Rineka Cipta

[13] Sambas. Muhidin dan Maman. 2007. Analisis Korelasi, Regresi dan Jalur dalam Penelitian, Bandung: Pustaka Setia

[14] Sardiman A. M. 2012. Interaksi dan Motivasi Belajar. Depok : PT Raja Grafindo Persada

[15] Sasmoko. 2005. Metode Penelitian Pengukuran dan Analisis Data, Jakarta:

Perpustakaan Nasional

[16] Setiawan, Mary. G. 2005. Pembaruan Mengajar ,Bandung : Yayasan Kalam Hidup

[17] Siswanto, Igrea. 2012. Anak Anda Pasti Berubah, Yogjakarta : Rineka Cipta

[18] Susana, Tjipta. 2007. Mempertimbangkan Hukuman Pada Anak, Yogyakarta: Kasinus

[19] Tim Pustaka Familia, 2006. Menepis Hambatan Tumbuh Kembang Anak, Yogyakarta: Kasinus.

[20] Tim Penyusun Buku dan Redaksi BPK Gunung Mulia, 2002. Memperlengkapi 
Bagi Pelayanan dan Pertumbuhan:

Kumpulan Karangan Pendidikan

Kristiani Dalam Rangka Penghormatan

Kepada Pdt. Prof. Dr. Robert $R$.

Boehlke, Jakarta, BPK Gunung Mulia.

[21] Tong, Stephen. 1993. Arsitek Jiwa,

Jakarta :Lembaga Reformed Injili

Indonesia. 